\title{
RENDEZETLEN ALKATRÉSZEK RAKODÁSI FOLYAMATÁNAK FEJLESZTÉSE
}

\author{
Magyar Gergely ${ }^{a}$, Sebestyén László Ádám ${ }^{a}$, Magyar Gábor $^{b}$, Andó Mátyás $^{c^{*}}$
}

${ }^{a}$ ELTE Informatikai, Kar, Savaria Müszaki Intézet, Gépészmérnöki BSc, 4. évf.

${ }^{b}$ BPW-Hungária Kft., gyártásautomatizálási csoportvezetó

c ELTE Informatikai, Kar, Savaria Múszaki Intézet, egyetemi docens

\begin{abstract}
ABSZTRAKT
Ebben a cikkben egy automatizált rakodó (bin-picking) rendszer kialakításának, illetve tovább fejlesztésének lépéseit fogjuk bemutatni. A rendszernek a feladata, hogy a rendezetlenül szállított tengelycsonkokat egy robot rendezetten a palettára helyezze. Az automatizált rendszer két elemét fogjuk részletesen bemutatni: a robotprogramot és forgató asztal múködését. Kitérünk a robotprogram fốés alprogramjai közötti összefüggésekre és a múködéshez megfelelő struktúra megvalósítására. A forgató asztal múködésének fejlesztését több lépésen keresztül mutatjuk be, szisztematikus mérésekkel igazolva az eredményeket. A rendszer múködóképességét azóta több ezer kipakolás is igazolja.
\end{abstract}

Kulcsszavak: bin-picking, robot, automatizálás

\section{Bevezetés}

A futómúgyártás folyamatának egyik jellegzetes eleme a futómúvek végén található tengelycsonkok gyártása. Ezek az alkatrészek félkész állapotban (előgyártmányként) kerülnek a gyártási folyamatba, ahol további megmunkálásokat végeznek el rajtuk. Szállításuk úgynevezett ládákban (vagy más szóval kalodákban) történik, melyekben a tengelycsonkok szabadon el tudnak mozdulni. Vagyis ömlesztett áruként érkeznek, rendezetlenül töltve ki a kalodát. Annak érdekében, hogy a megmunkáló központok kiszolgálása megfelelő legyen, valamilyen rendezett formában kell az alkatrészeket továbbítani. Korábban ezt a rendezési feladatot a megmunkáló központoknál dolgozó alkalmazottak végezték el. A tengelycsonkokat egyesével pozicionálták egy palettára, az emeléshez kézi darut használtak. Ez egy rendkívül lassú és körülményes folyamat, amely jelentôs időt vesz igénybe. Ezért célunk egy olyan rendszer létrehozása volt, amelyben a tengelycsonkok mozgatása robottal történik, illetve pozícióba forgatása is teljesen automatizált.

$\mathrm{Az}$ ömlesztett vagy rendezetlen áruk rakodására kifejlesztett automatizált rendszereket angolul „bin-picking” rendszereknek nevezzük. Ezek a rendezetlen áruk/alkatrészek egy tároló egységben vagy akár egy felületen helyezkednek el és valamilyen meghatározott elv alapján rendezzük ezeket [1]. Ehhez szükséges az alkatrészhalmaz detektálása, melyet különböző szenzorok és mérőeszközök összességéból álló rendszer biztosít. A detektálás után különböző algoritmusok vagy mesterséges intelligencia meghatározza azokat a darabokat, melyek mozdíthatók és továbbíthatóak a következő állapotba. A mozgatáshoz különbözó típusú robotokat alkalmaznak, talán a legelterjedtebb a 6tengelyes robotok alkalmazása, amivel a teljesen szabadon elhelyezkedő munkadarabok is rugalmasan megfoghatók [2, 3]. Hasonló felhasználásokra akár delta robotok alkalmazása is megfelelő, jellemzóen akkor, ha a munkadarabok síkfelületen helyezkednek el, illetve nagy sebességú robotmozgásra van szükség (például szállítószalagokon történô válogatás) [4]. Ezeken felül még SCARA robotok használata is előfordul, rezgôtálcás kiegészítéssel, amennyiben ugyancsak síkfelületen helyezkednek el az alkatrészek és a rakodás sebességigénye nem kritikus [5].

(C) ELTE, Informatikai Kar, Savaria Múszaki Intézet, 2021

*Kapcsolattartó: Andó Mátyás, am@inf.elte.hu

https://doi.org/10.37775/EIS.2021.1.6 
Az alkatrészek megfogáshoz gyakran univerzális két-három-négyujjas megfogókat használnak [6], de alkalmaznak speciális megfogószerkezeteket is, melyek például pneumatikus vagy mágneses elven múködnek [7]. Továbbá léteznek olyan rendszerek is, amelyek több megfogó használatát teszik lehetôvé, ezzel biztosítva több különböző alkatrész hatékony mozgatását [8, 9].

A rendszer kezdeti beüzemelési tapasztalatai alapján, a különbözô helyzeteket lekezelô robotprogram fô elveinek és a pozicionáló asztal fejlesztésének bemutatását tüztünk ki célul.

\section{Anyag és módszer}

A mozgatáshoz egy KUKA KR120 R2700 típusú hattengelyes robotot használtunk (120 kg teherbírással, $2701 \mathrm{~mm}$ karkinyúlással, 0,05 mm ismétlési pontossággal), amely egy MS-8140405 típusú permanens mágneses megfogóval és a rajta lévő egyedi tervezésû prizmákkal biztosítja a tengelycsonkok megfogását. A Wenglor MLSL255 típusú kontúrszkenner (kék fényú, 3R-es biztonsági osztályú lézerfényt bocsát ki, illetve a képalkotás során mozgatni szükséges) végigpásztázza a láda tartalmát, majd egy szoftver a feldolgozás után meghatározza a kivehető tengelycsonk koordinátáit és irányát. Az adatokat egy Siemens S7-1500-as PLC továbbítja a robotvezérlónek. A robot az adott darabot elôször a forgató asztalra helyezi, ahol a darab pontos helyzetbe forgatása megtörténik, majd a robot átemeli a darabot a palettára. A folyamatot az 1. ábra szemlélteti.

\section{Robotprogram müködési logikájának megalkotása}

A tengelycsonkok véletlenszerú helyzetéból adódóan a kipakolás során több jellemzô eset is kialakulhat a kalodában. A robotprogramnak ezeket az eseteket kell azonosítani és megfelelően lekezelni a folyamatos múködés érdekében. Az azonosított esetek a következók voltak:

1. a háromdimenziós modellel történt összehasonlítás után van kivehetô darab és sikerült a kiemelése,

2. a háromdimenziós modellel történt összehasonlítás után van kivehetố darab, de nem sikerült a kiemelése,

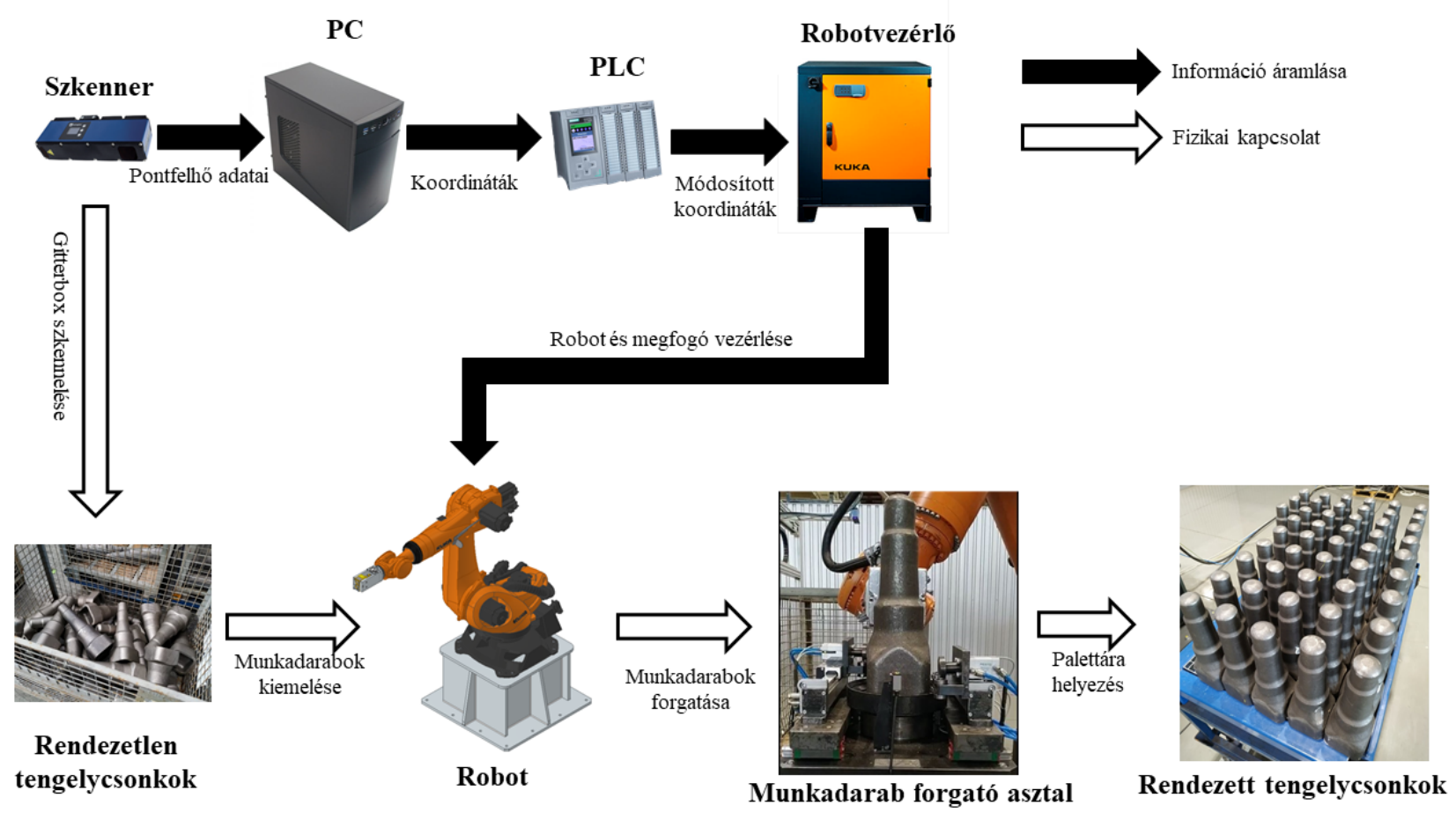

1. ábra: Rendszer elemeinek kapcsolódása 
3. a háromdimenziós modellel történt összehasonlítás után nincs kivehetô darab, de a munkadarabok átrendezésével már lehet kivehető darab,

4. a háromdimenziós modellel történt összehasonlítás után nincs kivehető darab, de darab potenciálisan elhelyezkedhet a holttérben,

5. a háromdimenziós modellel történt összehasonlítás után nincs kivehetô darab és a láda üres,

6. a munkadarab palettára helyezése után nincs továbbinak hely a palettán.

Az eseteket azonosítva a szükséges cselekvés is meghatározható. Ezeket figyelembe véve megalkottuk a kiber-fizikai rendszer munkafolyamatának modelljét (2. ábra), amely tartalmazza az aktív beavatkozási pontokat is.

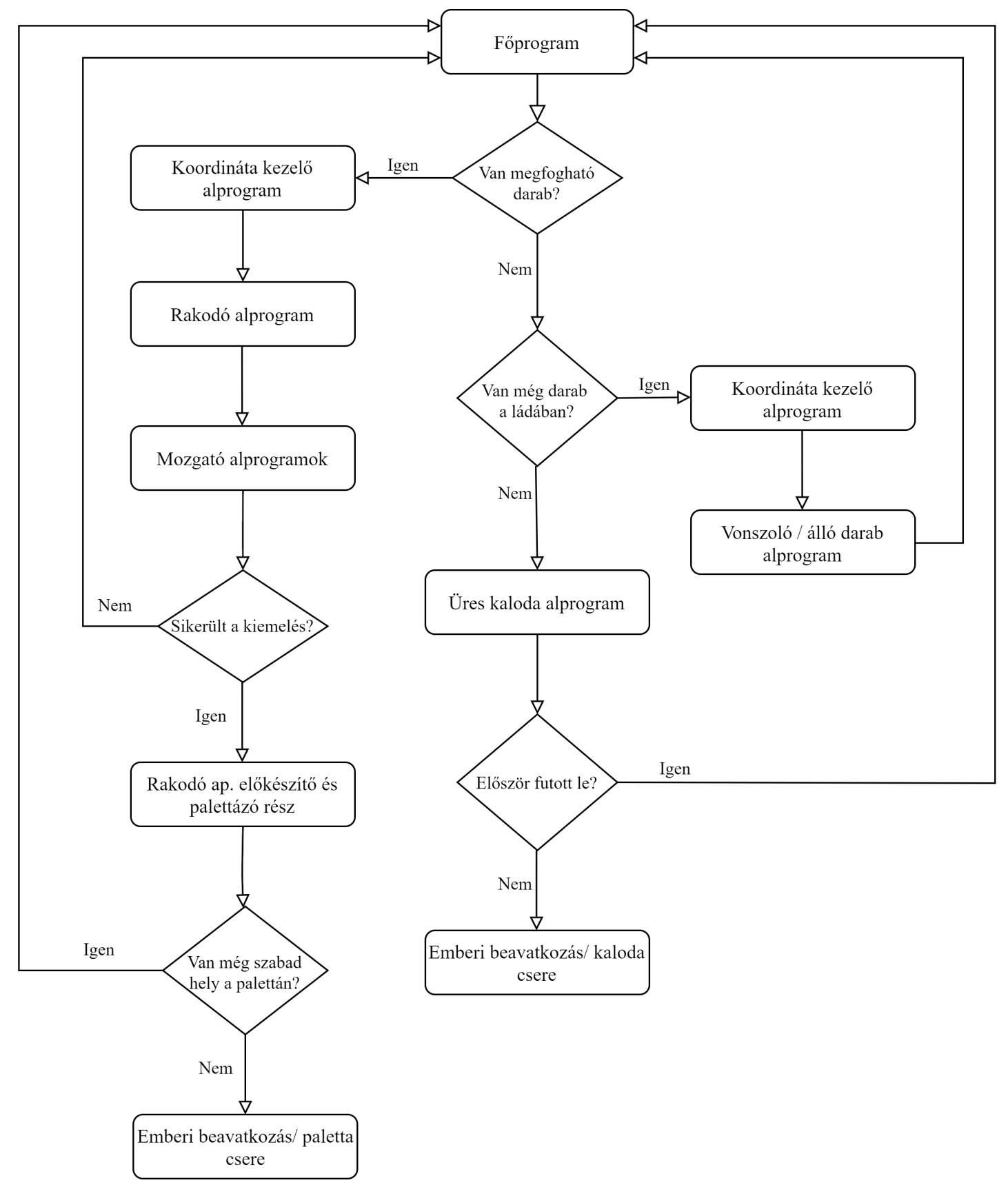

2. ábra: Robotprogram munkafolyamatának modellje 
Alap múködés esetén a háromdimenziós modellel történt összehasonlítás után van kivehetô darab és sikerült a kiemelése is. Ez a rendszer múködésének optimális esete. Amennyiben ez megtörtént egy következő szkennelési ciklussal folytatódhat a folyamat. Az utolsó ilyen beavatkozási pont akkor van, amikor a munkadarab palettára helyezése után nincs továbbinak hely a palettán (2. ábra, Emberi beavatkozás / paletta csere). Ekkora a folyamat megáll és a paletta cseréje után folytatódhat csak tovább a kirakodás. A második aktív beavatkozási pont az, amikor a kaloda kiürült. Ekkora a folyamat leáll és a munkadarabokat tartalmazó láda cseréje szükséges. Ezután újraindulhat a folyamat (2. ábra, Emberi beavatkozás / kaloda csere).

A harmadik beavatkozási pont, ha a modellel való összevetés során elsố alkalommal nem találunk megfogható darabot és a szoftver szerint nincs is alkatrész a ládában. Ilyenkor megvan az esély arra, hogy a láda széle által keltett holttérben nem érzékeljük a munkadarabot. Ekkor egy alprogramot hívunk meg, amely olyan robotmozgást tartalmaz, ami kimozgathatja a holttérból a munkadarabokat, így a következô szkennelés során a munkadarab érzékelése megtörténhet (2. ábra, Üres kaloda alprogram). Ennek az alprogramnak a múködését mutatja be a 3. ábrán látható képsorozat. Az a) képen megfigyelhetô a holttérben lévố alkatrész. Látható, hogy az alkatrész középre mozgatása már a c) képen megtörtént, de ettôl függetlenül a többi lehetséges helyet is ellenőrizni kell. A h) képen látható az alkatrész megfogása az újabb szkennelés után.

A negyedik beavatkozási eset, ha nincs kivehetô darab és ezért át kell rendezni a kaloda tartalmát. Ehhez szükség volt olyan alprogramra, amiben a robot nem kiveszi a munkadarabot, mindössze megváltoztatja a helyzetét a ládában. Külön kell kezelni azokat az eseteket, amikor a munkadarab helyzetét elegendő vízszintes irányban megváltoztatni, illetve amikor szükséges függóleges irányú mozgást is végezni. Elófordulhat olyan eset is, hogy a munkadarab álló helyzetben helyezkedik el a ládában, erre is külön mozgatási funkcióval kell készülni (2. ábra, Vonszoló / álló darab alprogram).

Ötödik eset, ha a háromdimenziós modellel történt összehasonlítás után van kivehetô darab, a megfogás meg is valósult, azonban a kiemelése nem sikerült. Ennek az ellenôrzésére egy optikai

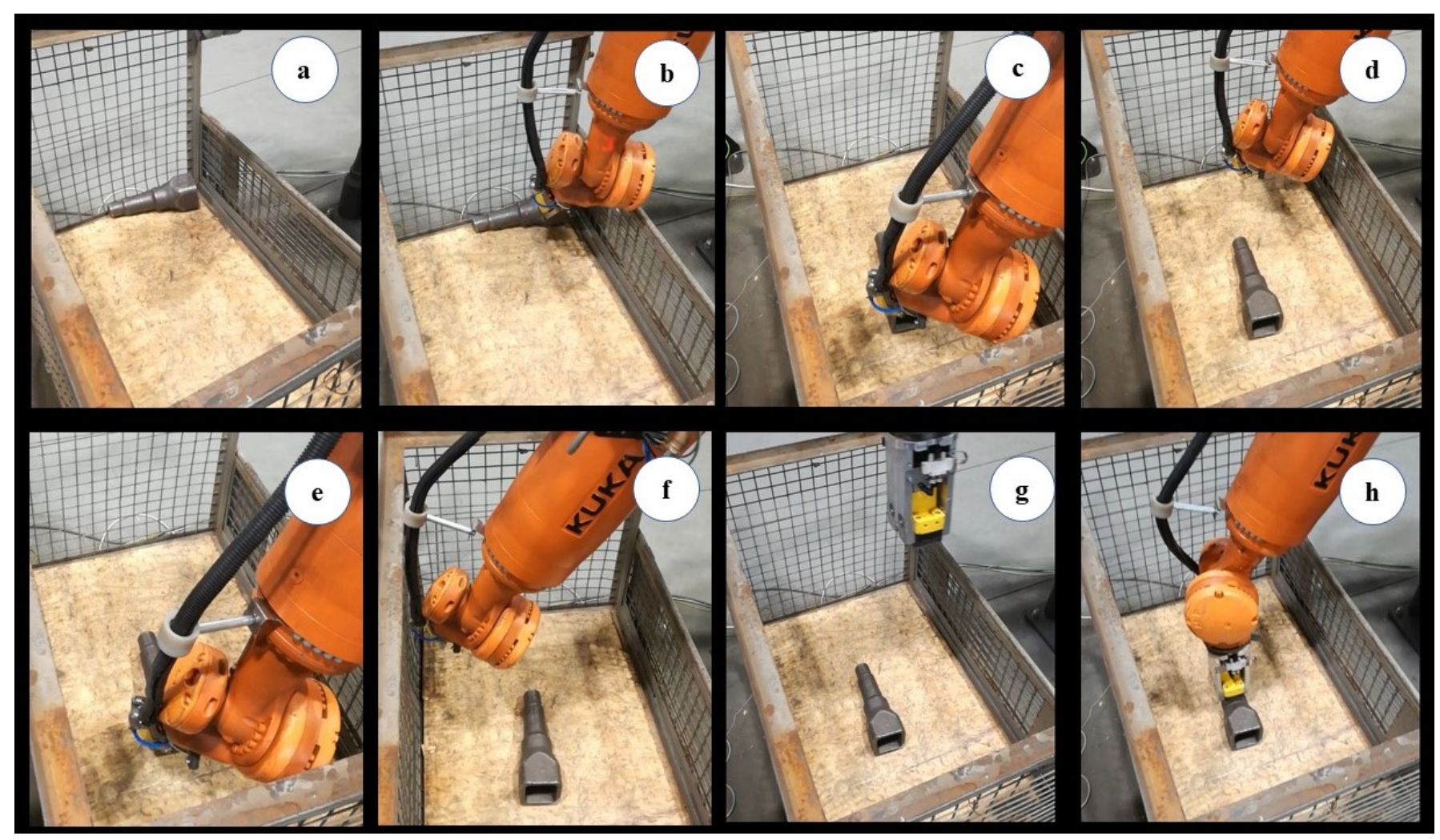

3. ábra: Üres kaloda alprogram folyamatának lépései 


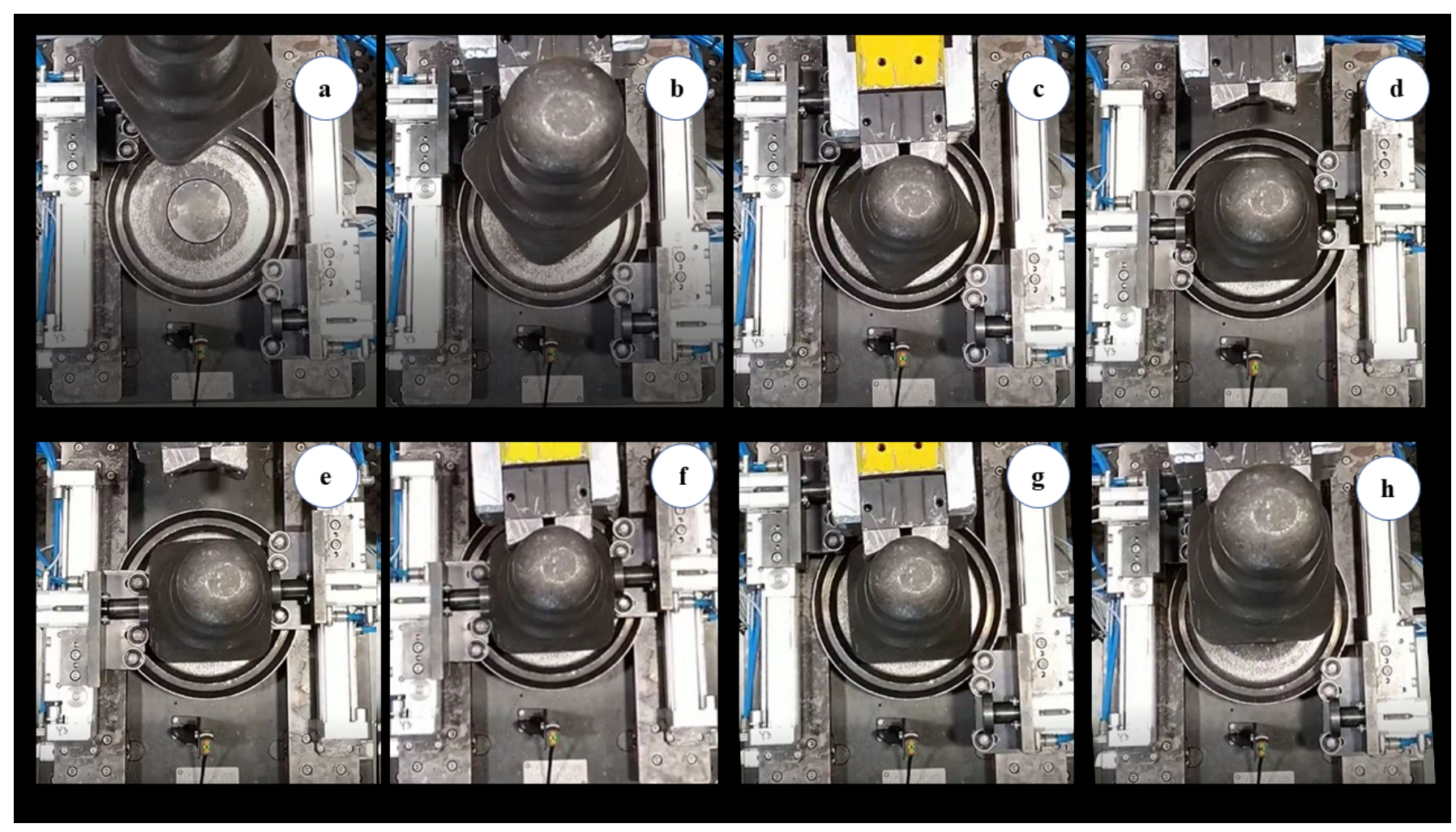

4. ábra: Munkadarab-forgatás lépései

szenzor van felhelyezve a megfogó szerkezetre, amely azt figyeli, hogy a kiemelés során a munkadarab a megfogó szerkezetben marad-e. Amennyiben nem, a kiemelési procedúra megáll és egy új szkennelési ciklus indul el.

Az eseteket rögzítésük és a beavatkozási megoldások kidolgozása után olyan strukturált robotprogramot készítettünk el, ami stabilan tudja szolgálni a kipakolást. A logikai egymásra épülés miatt az esetektől függóen a robot mindig az optimális beavatkozást fogja elvégezni.

\section{Munkadarab-forgató asztal fejlesztése}

A rendszer tervezése és megépítése után megkezdődött a tesztelési fázis. A kezdeti tesztek során jelentkezô problémák közül az előkészítô asztal beszorulásait mutatjuk be. A 4. ábrán látható munkadarab-forgató asztalon elhelyezett kocsik lineárisan mozognak és a tengelycsonk oldalával érintkezve elforgatják azt. Az a)-c) képig a munkadarab behelyezése, d)-e) képen a darab befogatása a kocsik segítségével és a $f$ )- $h$ ) képen pedig a kiemelés folyamata látható. Azonban megfigyeltük, hogy bizonyos munkadarab pozíciók esetén a két kocsi közé beszorult a munkadarab és a forgatás nem történt meg.

Az első kísérletekkel meghatároztuk azokat a helyzeteket, ahol a beszorulás előfordul. A tengelycsonkok négyzet keresztmetszetúek, ezért elég volt $0^{\circ}$ és $90^{\circ}$ közötti helyzeteket vizsgálni. Öt azonos típusú, de különböző munkadarabon egy fokonként forgatva, minden pozíciót háromszor ellenőrizve végeztük el a kísérleteket. Megfigyeltük, hogy a kocsik a rajtuk lévő görgókkel vagy elgördülnek a tengelycsonk sarkai mellett, vagy a sarkon felütközve eltolják azt a következô síknegyedbe (5. ábra). Például, ha a két vizsgált sík bezárt szöge $5^{\circ}$, akkor a kocsik elgördülnek a sarok mellett, és a rajtuk található egyenes rész $0^{\circ}$-os helyzetbe állítja a munkadarabot. Azonban, ha a két vizsgált sík bezárt szöge $45^{\circ}$, akkor a kocsi felütközik a munkadarab sarkán, és a kocsik $90^{\circ}$-os helyzetbe forgatják a darabot.

A kritikus helyzet a két jellemző forgatási mód közötti szöghelyzetekben történt, $13^{\circ}$ és $16^{\circ}$-os helyzetnél. Ezek alapján meghatároztuk azt a vizsgálati eljárást, amivel a konstrukciós módosítások 

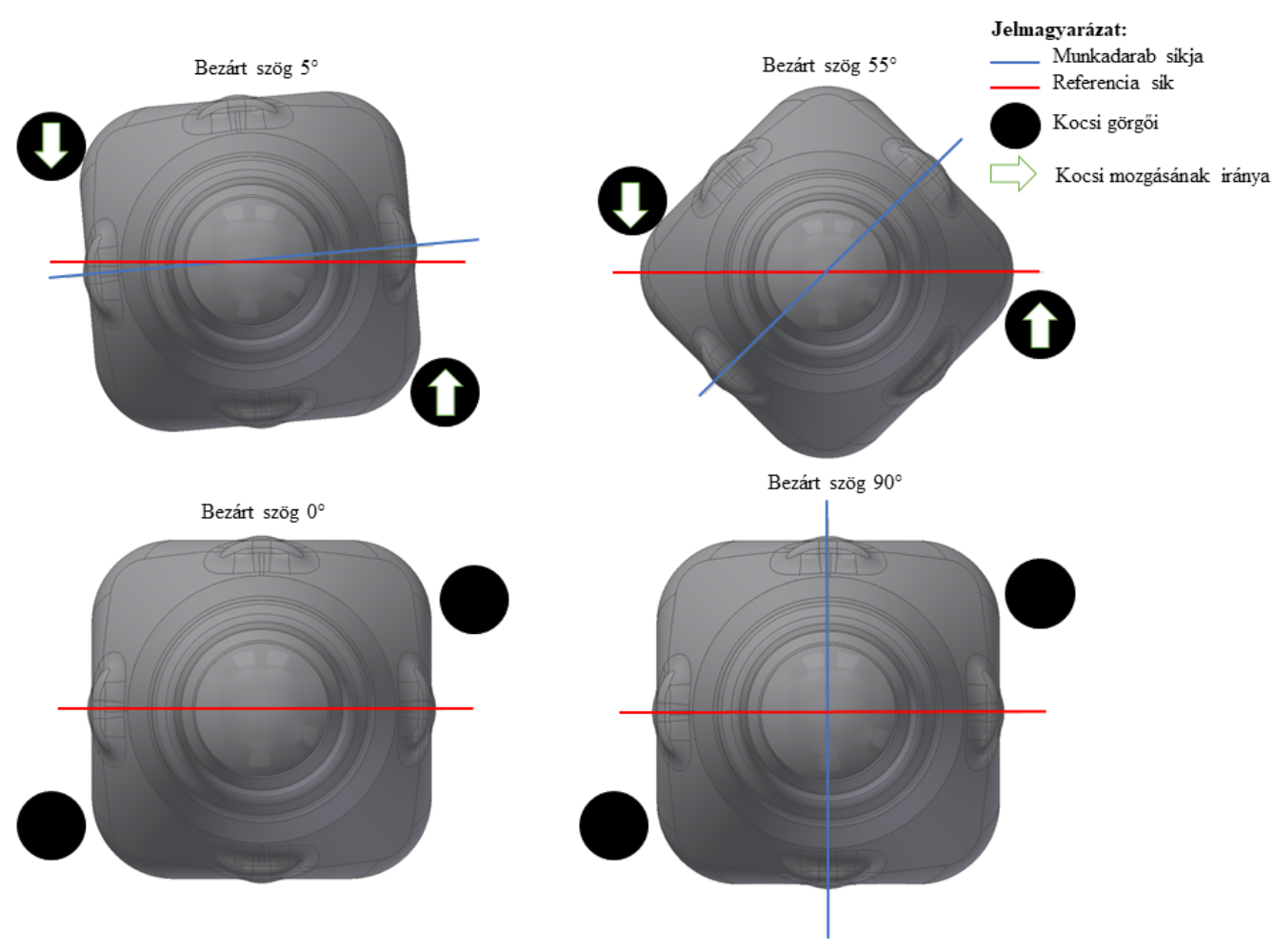

5. ábra: A munkadarab szöghelyzeteinek szemléltetése

sikerességét ellenőrizni fogjuk. $0^{\circ}$ és $12^{\circ}$ között, valamint $17^{\circ}$ és $90^{\circ}$ között minden értékre háromszor, míg $13^{\circ}$ és $16^{\circ}$ között minden értékre 10-szer kell elvégezni a forgatási vizsgálatot, mind az öt darab esetén. Az elsố konstrukciós változtatásnál a kocsik mozgatása el volt egymáshoz képest hangolva fojtószelepek segítségével. A mérések azt mutatták, hogy ez a megoldás nem segített elkerülni a beszorulásokat (6. ábra). Látszik, hogy továbbra is csak a 13-16º közötti tartomány a kritikus, máshol beszorulást nem tapasztaltunk.

A második megoldás a PLC program módosítása volt. Amennyiben beszorulás lépett fel a forgatás során, egy adott idő lejárta után a kocsik visszatértek az alap állapotba, majd újra megkísérelték a forgatást. Itt már a beszorulások jelentôs mennyiségét sikerült javítani (7. ábra). Látszik, hogy a beszorulások nagy részét ezzel a plusz mozgással korrigálni lehetett. A 25 beszorulásból csupán két esetben nem volt múködóképes a megoldás. Sajnos ez az érték azonban még mindig nem elfogadható a stabil múködés biztosításához.

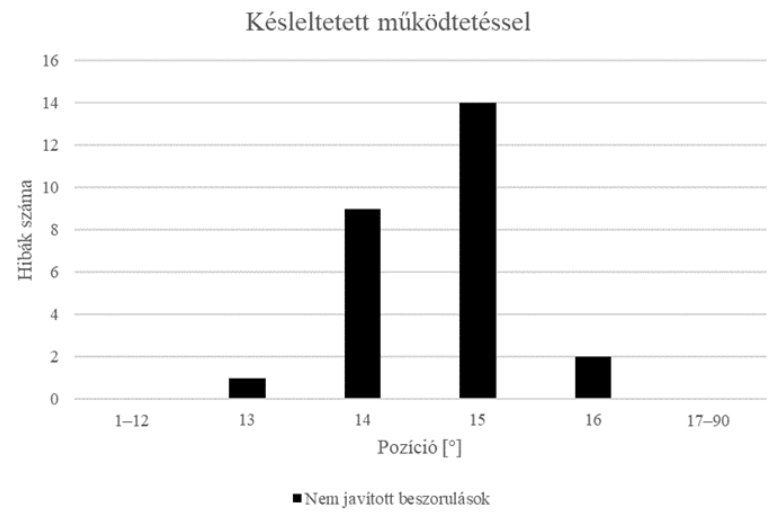

6. ábra: Elhangolt kocsikkal történt mérési eredmények

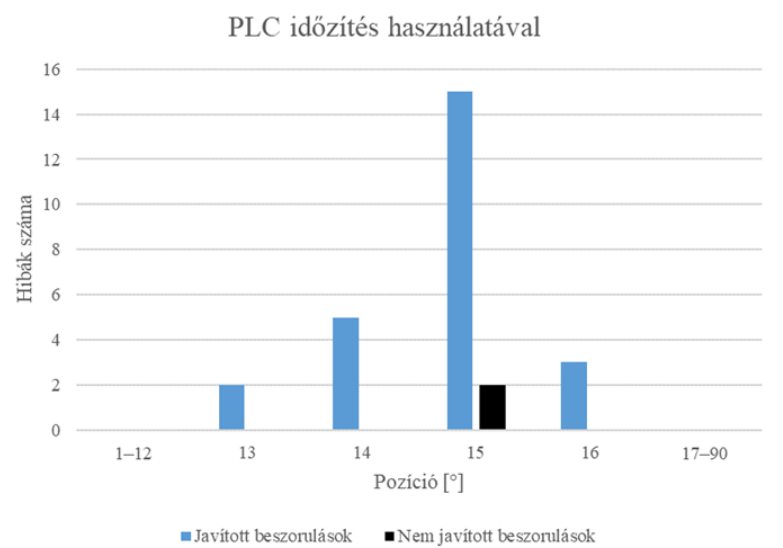

7. ábra: Idôzítés alkalmazásával végzett mérési eredmények 


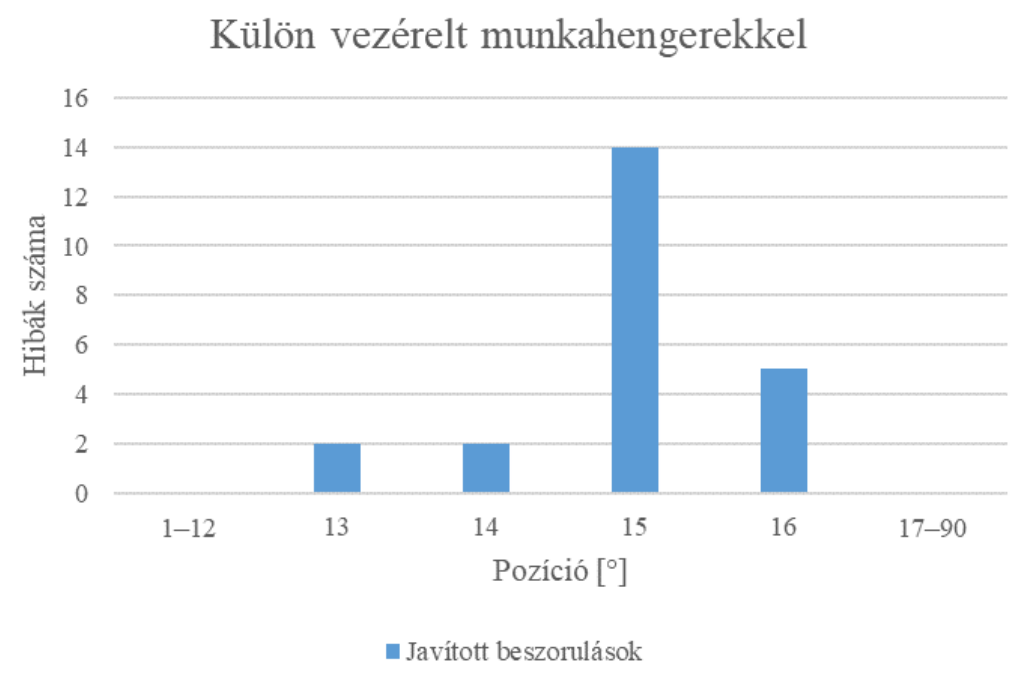

8. ábra: Külön vezérlet munkahengerekkel végzett mérési eredmények

A végsố megoldásnak az bizonyult, hogy külön szelepekkel vezéreltük a kocsikat mozgató munkahengereket, így amikor beszorulás történik, a munkahengerek alapállapotba állnak vissza, majd csak az egyik lép mozgásba, ezután késleltetve a másik. A 8. ábrán látszik, hogy így már minden beszorulást sikerült javítani. Vagyis a forgató asztalon a darab mindig pozícióba forgatható.

\section{5. Összefoglalás}

A cikkben röviden bemutattuk a rendszer alapvető elemeit, a közöttük lévő kapcsolatokat, illetve a múködésének az elvét. Utána bevezettük az alkalmazott robotprogram munkafolyamatának modelljét, amely minden munkadarab elhelyezkedésre mozgatási alternatívát nyújt. Az munkafolyamat modelljében bemutatott aktív beavatkozási pontok részletesen is ismertettük, amely biztosítja az optimális múködését a folyamatnak. Végül egy, a fejlesztés során elókerülő probléma több lépcsős megoldását is bemutattuk. Az egyes megoldások helyességét tesztekkel is alátámasztottuk.

A felépített architektúra megfelelően múködött már több ezer darab kipakolása során, így a robotprogram struktúráját ebben a formában véglegesítettük. Elmondható, hogy ez a koncepció a kalodában bármilyen orientációban elhelyezkedô munkadarabok kivételére alkalmas. További tapasztalat, hogy a forgató asztal beszorulásai nem befolyásolják nagymértékben a kipakolási idótartamot, hiszen csak esetlegesen fordulnak elő, illetve a szöghelyzet korrekciója is mindössze néhány másodpercet vesz igénybe.

\section{Köszönetnyilvánítás}

Készült az EFOP-3.5.1-16-2017-00012 „Duális és kooperatív felsőoktatási képzések, felsőoktatási szakképzési és szakirányú továbbképzések fejlesztése" címú projekt keretében.

\section{Irodalomjegyzék}

[1] D. Buchholz, Bin-Picking - New Approaches for a Classical Problem, Springer International Publishing, 2016, CrossRef

[2] C. Zhuang, Z. Wang, H. Zhao, H. Ding, Semantic part segmentation method based 3D object pose estimation with RGB-D images for bin-picking, Robotics and Computer-Integrated Manufacturing 68, 2021, 102086, CrossRef 
[3] K.N. Kaipa, A.S. Kankanhalli-Nagendra, N.B. Kumbla, S. Shriyam, S.S. Thevendria- Karthic, J.A. Marvel, S.K. Gupta, Semantic part segmentation method based 3D object pose estimation with $R G B$-D images for bin-picking, Addressing perception uncertainty induced failure modes in robotic bin-picking, Robot. Computer-Integrated Manufacturing 42, 2016, pp. 17-38, CrossRef

[4] J.P. Barreto, B. Corves, Resonant Delta Robot for Pick-and-Place Operations. In: Uhl T. (eds) Advances in Mechanism and Machine Science, IFToMM WC 2019 Mechanisms and Machine Science 73, 2019, pp. 2309-2318, CrossRef

[5] Z. Wang, Y. Xu, Q. He, Z. Fang, G. xu, J. Fu, Grasping pose estimation for SCARA robot based on deep learning of point cloud, International Journal of Advanced Manufacturing Technology 108, 2020, pp. 1217-1231, CrossRef

[6] M. Moosmann, F. Spenrath, K. Kleeberger, M.U. Khalid, M. Mönnig, J. Rosport, R. Bormann, Increasing the Robustness of Random Bin Picking by Avoiding Grasps of Entangled Workpiece, Procedia CIRP, 93, 2020, pp. 1212-1217, CrossRef

[7] M. Alonso, A. Izaguirre, M. Graña, Current Research Trends in Robot Grasping and Bin Picking, International Joint Conference SOCO'18-CISIS'18-ICEUTE'18, San Sebastián, Spain, 6-8 June 2018, pp. 367-376, CrossRef

[8] M. Moghaddam, S.Y. Nof, Parallelism of Pick-and-Place operations by multi-gripper robotic arms, Robotics and Computer-Integrated Manufacturing 42, pp. 135-146, CrossRef

[9] A. Iriondo, E. Lazkano, A. Ansuategi, Affordance-Based Grasping Point Detection Using Graph Convolutional Networks for Industrial Bin-Picking Applications, Sensors 21(3), 2021, 816, CrossRef 